\title{
BM] Global Health The sociopolitical context of the COVID-19 response in South Korea
}

\author{
Hani Kim
}

To cite: Kim H. The sociopolitical context of the COVID-19 response in South Korea. BMJ Global Health 2020;5:e002714. doi:10.1136/ bmjgh-2020-002714

Received 23 April 2020 Revised 26 April 2020 Accepted 28 April 2020

A) Check for updates

(c) Author(s) (or their employer(s)) 2020. Re-use permitted under CC BY-NC. No commercial re-use. See rights and permissions. Published by BMJ.

Global Health, Bill \& Melinda Gates Foundation, Seattle, Washington, USA

Correspondence to

Dr Hani Kim;

hanikim584@gmail.com

\section{INTRODUCTION}

The first case of COVID-19 was confirmed in South Korea on 20 January 2020. The epidemic reached a plateau by 12 March. ${ }^{1}$ The WHO and others have praised Korea's COVID-19 control and attributed Korea's success mainly to two factors: (1) extensive testing using the latest molecular diagnostic kits and innovative testing strategies (eg, drivethru and walk-thru testing) and (2) contact tracing to support effective epidemiological investigations. $^{2}$ These strategies undoubtedly contributed to Korea's COVID-19 control. ${ }^{34}$ However, the publicised 'lessons from Korea' overlook the sociopolitical context and treat these policy interventions as if they operate as depoliticised variables disconnected from the surrounding social and political processes.

In other words, there is a prevailing tendency to sanitise the lessons of their political dimension and to reduce them to a matter of developing and deploying technological interventions and improving managerial efficiency in scaling them far and wide. This tendency to depoliticise health problems and solutions has been described by myself and others as one of the persistent characteristics of the dominant norms in global health. ${ }^{56}$ Depoliticising solutions to a public health problem limits what we can observe and imagine as policy choices. In times of a pandemic of an unprecedented scale in modern times, this is a limitation we cannot afford. COVID-19 challenges us to fundamentally rethink what it means to envision public health programmes and policies in a globalised world.

A globalised world means a globalised economy; it is characterised by the movement of capital (in the forms of goods and services) and labour (people) on the one hand and concentration of wealth within small social groups within countries on the other hand. ${ }^{78}$ Two defining features of a globalised economy are interconnectedness and inequity. Evidently, COVID-19 affects

\section{Summary box}

The existing reports tend to portray the effective interventions and policies as if they operate independently of the surrounding political and socia processes. As a result, these reports have limited insights and public health value for diverse health system contexts, especially more resource-constrained settings.

- In times of a global pandemic of an unprecedented scale that has shaken the human societies as profoundly as COVID-19 has, it is urgent for us to collectively challenge ourselves to think beyond the business-as-usual mode and to imagine new approaches and collaborations for pandemic preparedness over the long term.

- Situating the lessons from COVID-19 control efforts within a specific sociopolitical context is necessary to maximise insights on how specific public health programmes and policies may work in specific contexts.

- To illustrate this, I highlight the key systems-level features underlying South Korea's response to COVID-19, including the role of public investment and trust, and of democracy, equity and solidarity, in response to disease outbreaks and the overall resilience of the health system.

everyone, and it does not affect everyone equally. The question of who is more likely to develop severe disease and die than others is not merely one of the virus and the host. It is a question of who could afford to exercise social distancing, lose jobs, endure pay-cuts and access essential commodities in times of supply-chain disruption and heightened food insecurity.

More than ever, we need to critically reflect on the lessons from all corners of the world with an eye to challenge the implicit norms and imagine new approaches and collaborations to solve a public health problem that has shaken the human societies as profoundly as COVID-19 has. In this commentary, I highlight the key systems-level policies underlying Korea's response to COVID-19 and situate them in Korea's sociopolitical context. 


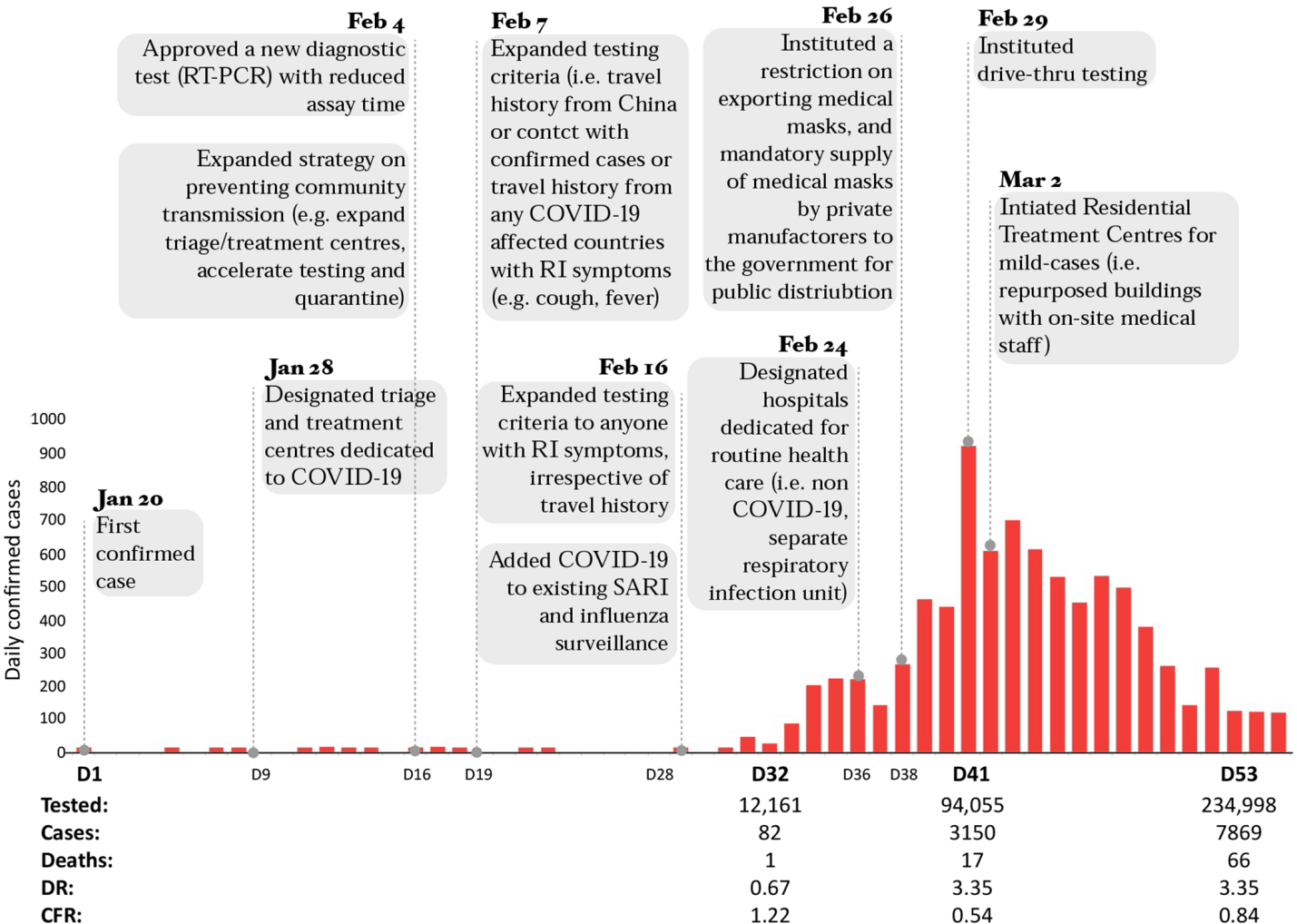

Figure 1 Government policies instituted. Cases=RT-PCR positive for SARS-CoV2 irrespective of clinical symptoms. $\mathrm{DR}=$ cases/total tested. CFR=deaths/confirmed case. Data Source, Korean Ministry of Health and Welfare briefing reports. CFR, case fatality rate; DR, detection rate; RI, respiratory infection; SARI, severe acute respiratory infection; SARS-CoV2, severe acute respiratory syndrome coronavirus-2; RT-PCR, reverse transcription polymerase chain reaction.

\section{A SYSTEM-WIDE COVID-19 PANDEMIC RESPONSE}

COVID-19 has been contained in South Korea, though tenuously, with a total of 455032 suspected cases tested, 10156 confirmed cases and 177 deaths as of 4 April. $^{1}$ Policies were implemented to enable a system-wide emergency response (figure 1). ${ }^{134}$ New molecular diagnostic tests were developed for detecting the severe acute respiratory syndrome-coronavirus 2 (SARS-CoV2), the etiological agent of COVID-19, with reduced assay time from days to less than 6 hours. Approval of the new test was accelerated through the Emergency Use Approval System by the Korean Ministry of Food and Drug Safety. ${ }^{3}$ Innovative testing strategies enabled a rapid deployment of large-scale testing of suspected cases. ${ }^{9}$

Active detection of SARS-CoV2 infection irrespective of clinical symptoms enabled a triage system to stratify the infected individuals according to the risk of developing severe disease. In order to reduce strain on tertiary hospitals, public or private buildings were converted to residential treatment centres for dedicated treatment of mild cases, with on-site medical staff, while patients with or at risk of developing severe COVID-19 disease were prioritised for tertiary hospitals. Hospital transmission was minimised by designating separate hospitals and wards for individuals suspected of SARS-CoV2 infection from those with non-COVID-19 illnesses. ${ }^{1}$

New information and communication technology tools (eg, mobile phone data and apps) were developed (1) to actively identify new infections via contact tracing; (2) to safely guide self-monitoring during home quarantine, which was integrated into public health facilities; and (3) to enable timely and transparent risk communication by public health authorities to the public. ${ }^{1}$ The three factors contributed to minimising community transmission and gaining the public trust in the government's pandemic response.

Months of social distancing resulted in an enormous strain on the livelihood of small businesses, low-income families, undocumented foreign migrant workers and workers with precarious employment conditions. ${ }^{4}$ As unemployment is soaring and the economy is contracting to an unprecedented degree, the full impact of COVID-19 on the livelihood of Koreans and the outcomes of the government's social welfare policies to mitigate it remain to be seen.

\section{HEALTH SYSTEMS CONTEXT: PUBLIC INVESTMENT AND TRUST}

South Korea's healthcare system, the Social Health Insurance (SHI), was established in $1977 .{ }^{10}$ Financed jointly by employers and employees, the SHI had a limited coverage to a small number of employees of large companies. The SHI expanded to universal coverage in 1989 and was eventually transformed into a governmentfunded (single-payer) National Health Insurance (NHI) for all citizens in $2000 .{ }^{10}$ Within the Korean NHI system, 
healthcare is mainly provided by private health facilities. South Korea ranks 46th highest in the gross domestic product per capita of $\$ 39500$ and spends $\$ 2431$ /year/ capita (cf. $\$ 9403 /$ year/capita for the USA) ${ }^{11} 12$

Korea's health system significantly benefitted from public investments made to establish emergency response mechanisms across multiple ministries and levels of the government after two epidemics prior to COVID19. Pandemic influenza A/H1N1 caused 750000 cases and 252 estimated deaths in South Korea between May 2009 and August 2010. ${ }^{13}$ Between May and November of 2015, the Middle East respiratory syndrome coronavirus (MERS-CoV) caused 186 confirmed cases and 38 deaths. ${ }^{14}$

During the MERS-CoV outbreak, the conservative government was heavily criticised by the public for delayed testing, failure to identify and isolate 'super spreaders', which exacerbated hospital transmission, and lack of transparency in risk communication to the public. The two outbreaks triggered a rigorous public debate on the conflicting needs between protecting personal data and ensuring collective well-being during epidemics. The public demand for a system-wide reform in epidemic preparedness led to strengthening the Korean Centers for Disease Control and Prevention (KCDC) in 2016 and establishing the provincial-level rapid response teams under KCDC's leadership. Emergency response mechanisms were put in place with the KCDC as the main technical lead under the Ministry of Health and Welfare, but with an extensive collaboration across ministries. ${ }^{34}$

Subnational governments at the city and the provincial levels were empowered to develop and implement emergency response within the national government's emergency response framework. The Infectious Disease Prevention and Control Act was legislated in December 2015 to permit collection and sharing of personal data by the government for the sole purpose of prevention and control of infectious diseases. ${ }^{15}$ In short, epidemic preparedness was recognised as a core public health function after the two outbreaks, and emergency response mechanisms for coordination and collaboration across ministries and subnational governments were put in place prior to the COVID-19 outbreak.

Lastly, a nationwide popular uprising in 2016-2017 impeached President Park Geun-Hye, who served between 2013-2017 on a series of corruption charges and led to the election of the current government in 2017. This political context is relevant to interpreting the relatively high level of public trust in and support for the current government, and the active participation of the civil society in the government's COVID-19 control efforts.

\section{REFLECTIONS ON RESILIENCE: DEMOCRACY, EQUITY AND SOLIDARITY}

A timely and coordinated response to COVID-19 outbreak in South Korea was possible largely because of the system-wide epidemic response mechanisms that were established after the MERS-CoV outbreak. It is the result of a policy decision which allocated resources and decision-making authorities to strengthen the relevant public institutions to respond to emergency public health needs. The outcomes expose the existing social inequalities and highlight the fragile nature of the existing mechanisms as long-term strategies.

First, democratic and transparent governance were critical in inducing active civic participation in the COVID-19 control. However, the social contract between citizens and government is inherently tentative and dynamic. Use of personal data for public good will continue to be sensitive, and it must be calibrated through democratic deliberation.

Second, epidemic blind spots put the entire population at risk, thus making an equity focus a necessity. Is a series of just-in-time emergency cash transfers sustainable or even effective in the long run? Is there an argument for strengthening social protection floor that can proactively identify and protect the vulnerable social groups, and strengthen resilience at a systems level?

Third, pandemic response heightens anxiety and can increase distrust among individuals and communities. How can we envision pandemic preparedness without fracturing communities, and strengthen social cohesion and resilience? Beyond targeting disease-causing pathogens with diagnostics, treatments and vaccines, long-term strategies for pandemic preparedness must be rooted in the principles of democracy, equity and solidarity, without which a resilient society is difficult to imagine.

Twitter Hani Kim @HaniKim_hk

Acknowledgements I thank Uros Novakovic from Office Ou, Toronto, Canada, for his insightful feedback on the manuscript, and Taehyung Kim from the Graham Baba Architects, Seattle, USA, for his help with the figure. I am indebted to Ji-Young Park, an infectious disease nurse at the CHA Hospital, Seoul, Korea for her valuable insights on the clinical triage system for COVID-19 amid her challenging times of working as a frontline healthcare worker.

Collaborators Uros Novakovic.

Contributors $\mathrm{HK}$ is the sole author of this paper.

Funding The authors have not declared a specific grant for this research from any funding agency in the public, commercial or not-for-profit sectors.

Disclaimer Views presented in this article are solely those of the author, and do not represent the views, interests, or funded work of the Bill \& Melinda Gates Foundation.

Competing interests None declared.

Patient consent for publication Not required.

Provenance and peer review Not commissioned; internally peer reviewed.

Data availability statement There are no data generated in this work.

Open access This is an open access article distributed in accordance with the Creative Commons Attribution Non Commercial (CC BY-NC 4.0) license, which permits others to distribute, remix, adapt, build upon this work non-commercially, and license their derivative works on different terms, provided the original work is properly cited, appropriate credit is given, any changes made indicated, and the use is non-commercial. See: http://creativecommons.org/licenses/by-nc/4.0/.

ORCID iD

Hani Kim http://orcid.org/0000-0001-5963-4305 


\section{REFERENCES}

1 Korean Ministry of Health and Welfare. Available: http://ncov.mohw. go.kr/tcmBoardList.do?pagelndex=16\&brdld=3\&brdGubun=\&board id=\&search_item=1\&search_content= [Accessed 6 Apr 2020].

2 New York Times. How South Korea flattened the curve, 2020. Available: https://www.nytimes.com/2020/03/23/world/asia/ coronavirus-south-korea-flatten-curve.html [Accessed 1 Apr 2020].

3 The Government of the Republic of Korea. Flattening the curve on COVID-19, 2020. Available: https://mois.go.kr/eng/bbs/type002/ commonSelectBoardArticle.do?bbsld=BBSMSTR_000000000022\& nttld=76748 [Accessed 21 Apr 2020].

4 The Government of the Republic of Korea. Tackling COVID-19, health, quarantine and economic measures: Korea experience, 2020. Available: http://english.moef.go.kr/pc/selectTbPressCenterDtl.do? boardCd=N0001\&seq=4868 [Accessed 21 Apr 2020].

$5 \mathrm{Kim} \mathrm{H}$, Novakovic $\mathrm{U}$, Muntaner $\mathrm{C}$, et al. A critical assessment of the ideological underpinnings of current practice in global health and their historical origins. Glob Health Action 2019;12:1651017.

6 Ottersen OP, Dasgupta J, Blouin C, et al. The political origins of health inequity: prospects for change. The Lancet 2014;383:630-67.

7 Piketty T. Global inequality of wealth in the twenty-first century. In: Capital in the twenty-first century. Cambridge, MA: The Belknap Press of Harvard University Press, 2014: 430-8.
8 Milanovic B. The rise of the global middle class and global plutocrats. In: Global inequality: a new approach for the age of globalization. Cambridge, MA: The Belknap Press of Harvard University Press, 2016: 24-41.

9 the Hankyoreh News. 57 new COVID-19 cases in Gyongnam. Available: http://www.hani.co.kr/arti/area/yeongnam/930401.htm [Accessed 6 Apr 2020].

10 Lee S-Y, Kim C-W, Seo N-K, et al. Analyzing the historical development and transition of the Korean health care system. Osong Public Health Res Perspect 2017;8:247-54.

11 CIA Factbook: South Korea. Available: https://www.cia.gov/library/ publications/the-world-factbook/geos/ks.html [Accessed $1 \mathrm{Apr}$ 2020].

12 WHO country profile: South Korea. Available: https://www.who.int/ countries/kor/en/ [Accessed 1 Apr 2020].

$13 \mathrm{Kim}$ JY. The $2009 \mathrm{H} 1 \mathrm{~N} 1$ pandemic influenza in Korea. Tuberc Respir Dis 2016;79:70-3.

$14 \mathrm{Kim} \mathrm{KH}$, Tandi TE, Choi JW, et al. Middle East respiratory syndrome coronavirus (MERS-CoV) outbreak in South Korea, 2015: epidemiology, characteristics and public health implications. $J$ Hosp Infect 2017:95:207-13.

15 Infectious disease prevention and control act. Available: https://elaw klri.re.kr/kor service/lawView.do?hseq=40184\&lang=ENG [Accessed 1 Apr 2020]. 